\title{
ASPEK TEKNIK DAN KELAYAKAN USAHA PENGERINGAN IKAN TERI (Stolephorus sp) DI DESA AMBESIA SELATAN KECAMATAN TOMINI KABUPATEN PARIGI MOUTONG SULAWESI TENGAH
}

\author{
ENGINEERING AND TECHNICAL ASPECTS OF TERI DRY FISH \\ (Stolephorus sp.) IN SOUTH AMBESIA VILLAGE, TOMINI \\ DISTRICT, PARIGI MOUTONG SULAWESI DISTRICT
}

\author{
Emma Sosiawati*1 \\ ${ }^{1}$ Program Studi Agrobisnis Perikanan, Fakultas Perikanan Universitas Alkhairaat Palu \\ Jl. Diponegoro No. 39 Palu 94221 Sulawesi Tengah, Indonesia
}

\begin{abstract}
ABSTRAK
Penelitian ini bertujuan untuk mengetahui teknik pengeringan ikan teri (Stolephorus sp.) di Desa Ambesia Selatan Kecamatan Tomoni dan untuk mengetahui kelayakan usaha pengeringan ikan teri (Stolephorus sp) di Desa Ambesia Selatan Kecamatan Tomoni Kabupaten Parigi Moutong Provinsi Sulawesi Tengah. Pengumpulan data dalam penelitian adalah teknik wawancara, pengamatan, serta partisipasi aktif penulis bersama pemilik usaha pengawetan ikan di Desa Ambesia Selatan Kecamatan Tomini. Data diolah dengan analisis desktiptif kualitatif dan kuantitatif. Hasil penelitian ini menunjukkan bahwa secara teknik dan ekonomik usaha pengeringan ikan teri (Stolephorus sp) layak untuk dikembangkan. Analisis ekonomi untuk perhitungan pendapatan bersih secara keseluruhan 5 responden sebesar Rp. 188.295.100 per tahun, bila di hitung perorang nelayan responden, maka diperoleh pendapatan bersih pertahun Rp. 37.659.020, dan dikonversi 12 bulan (1 tahun) nilanya mencapaia Rp. 3.138 .251 perbulan. Sementara analisis kelayakan usaha pengeringan ikan teri diperoleh Benefit Cost Ratio sebesar 2.10.
\end{abstract}

Kata kunci: Aspek teknik; kelayakan usaha; pengeringan ikan teri; Parigi Moutong

\begin{abstract}
This research aims to find out anchovy drying technique (Stolephorus sp.) and the feasibility of anchovy drying business (Stolephorus sp.) in South Ambesia village of Tomini district of Parigi Moutong regency of Central Sulawesi Province. Data collections in this research were interview technique, observation, and active participation of the writer along with the fish preservation business owner in South Ambesia village of Tomini district. The data were processed by qualitative and quantitative descriptive analysis. The research results show that in technically and economically, the effort to dry anchovy (Stolephorus sp) was feasible to be developed. Economic analysis for the calculation of overall net income of 5 respondents amounting to Rp.188,295,100 per year, if the respondent per fisherman is counted, a yearly net income of Rp. 37,659,020, and converted 12 months (1 year) the value reached $R p .3,138,251$ per month. While the feasibility analysis of the anchovy drying business obtained a Benefit Cost Ratio of 2.10.
\end{abstract}

Keywords: Technical aspects; business feasibility; anchovy arying; Parigi Moutong

\section{Pendahuluan}

Besarnya potensi sumberdaya perikanan dan kelautan yang tersedia belum dimanfaatkan secara optimal, kontribusi sektor perikanan dan kelautan terhadap sektor pembangunan daerah

\footnotetext{
${ }^{*}$ Penulis Korespondensi.

E-mail: sosiawatiemma@gmail.com

HP : 08114510380
}

secara umum dan pembangunan masyarakat pesisir secara khusus masih rendah. Di samping itu pemanfaatan sumberdaya perikanan dan kelautan belum memperhatikan kaidah-kaidah pelestarian lingkungan sehingga terjadi degradasi dan deplesi sumberdaya yang mengarah kepada menurunnya potensi sumberdaya perikanan dan kelautan nasional. 
Menurut Ismail (2007), ikan merupakan sumber gizi yang sangat penting bagi tubuh.Kandungan proteinya cukup tinggi dengan susunan asam amino yang cukup lengkap. Kandungan lemaknya pun cukup rendah. Kandungan asam lemaknya sebagian besar merupakan asam lemak tak jenuh ganda terutama asam lemak omega-3 yang dapat menurunkan kadar kolesterol, meningkatkan kecerdasan, dan mencegah penyakit degeneratif.

Ikan tergolong bahan makanan yang cepat mengalami pembusukan dibandingkan dengan bahan makanan lain. Proses pembusukan ini pada umumnya disebabkan oleh proses kimia (oksidasi), proses mikrobiologis terutama bakteri, dan proses biokimia (enzym). Pada dasarnya ketiga proses tersebut berjalan bersama-sama sesaat setelah ikan itu mati. Ikan cepat busuk dan rusak bila dibiarkan di udara terbuka (kira-kira 58 jam setelah tertangkap). Oleh karena itu, ikan yang sudah ditangkap selain langsung dijual, dapat diolah atau diawetkan guna memperpanjang masa simpan dan distribusinya (Ismail, 2007).

Menurut Hasibuan (2005) bahwa bahasa pengeringan merupakan penghidratan, yang berarti menghilangkan air dari suatu bahan. Proses pengeringan atau penghidratan berlaku apabila bahan yang dikeringkan kehilangan sebahagian atau keseluruhan air yang dikandungnya. Proses utama yang terjadi pada proses pengeringan adalah penguapan. Penguapan terjadi apabila air yang dikandung oleh suatu bahan teruap. Hal ini terjadi apabila panas diberikan kepada bahan tersebut. Panas ini dapat diberikan melalui berbagai sumber, seperti kayu api, minyak dan gas, arang, batu ataupun tenaga surya.

Proses pengeringan dapat meningkatkan daya awet ikan karena dapat disimpan cukup lama dan dalam keadaan layak sebagai makanan manusia. Pengeringan merupakan proses penurunan kadar air bahan sampai mencapai kadar air tertentu sehingga dapat memperlambat laju kerusakan produk akibat aktivitas biologi dan kimia. Pengeringan pada dasarnya merupakan proses perpindahan energi yang digunakan untuk menguapkan air yang berada dalam bahan, sehingga mencapai kadar air tertentu agar kerusakan bahan pangan dapat diperlambat. Kelembapan udara pengering harus memenuhi syarat yaitu sebesar 55-60\% (Pinem, 2004).
Meskipun pengeringan itu akan mengubah sifat daging ikan dari sifatnya ketika masih segar, tetapi nilai gizinya relatif tetap. Kadar air yang mengalami penurunan akan mengakibatkan kandungan protein di dalam bahan mengalami peningkatan. Selama pengeringan juga terjadi perubahan antara lain warna menjadi cokelat. Perubahan warna tersebut dikarenakan reaksi browning. Reaksi browning nonenzimatis pada ikan yang paling sering terjadi adalah reaksi antara asam organik dengan gula pereduksi, serta antara asam-asam amino dengan gula pereduksi disebut juga reaksi Maillard. Reaksi antara asamasam amino dengan gula pereduksi dapat menurunkan nilai gizi protein yang terkandung di dalamnya. Vitamin - vitamin yang terdapat dalam bahan pangan yang dikeringkan akan mengalami penurunan mutu, hal ini disebabkan karena ada berberapa vitamin yang tidak tahan terhadap suhu tinggi. Proses pengeringan yang berlangsung pada suhu yang sangat tinggi akan menyebabkan terjadinya case hardening, yaitu bagian permukaan bahan pangan sudah kering sekali bahkan mengeras sedangkan bagian dalamnya masih basa (Hasibuan, 2005).

Ikan hasil pengeringan tanpa bantuan sinar matahari secara langsung justru memiliki kelebihan dibanding dengan ikan yang dikeringkan secara langsung dengan matahari. Karena pada ikan-ikan yang dikeringkan secara langsung (dijemur) sangat rawan terhadap serangan lalat dan kontaminasi kotoran selama penjemuran sehingga hal ini justru dapat mempengaruhi daya simpan ikan. Bila pengeringan dengan dijemur itu tidak sempurna justru dapat menyebabkan ikan mudah busuk terutama karena serangan jamur, belatung dan kutu. Prinsip dasar pengeringan adalah terjadinya penguapan air ke udara karena perbedaan kandungan uap air antara udara dengan bahan yang dikeringkan. Dalam hal ini, kandungan uap air udara lebih sedikit atau udara mempunyai kelembapan nisbi yang rendah sehingga terjadi penguapan (Adawiyah, 2007).

Desa Ambesia Selatan merupakan salah satu desa di Kecamatan Tomini Kabupaten Parigi Moutong Provinsi Sulawesi Tengah yang sebagian besar penduduknya berprofesi sebagai nelayan, diantaranya terdapat alat tangkap bagan perahu. Salah satu hasil tangkapan bagan perahu yang cukup dominan adalah ikan teri (Stolephorus sp.). Jika pada saat ikan hasil tangkapan berlimpah maka harga ikan segar akan menurun sehingga untuk menstabilkan harga, 
maka masyarakat pesisir mengeringkannya menjadi ikan asin.

Ikan Teri merupakan salah satu komponen ikan pelagis yang ditemukan di perairan tropis dan sub tropis dengan kondisi perairan tidak keruh dan tidak berlumpur. Ikan teri hidup dipermukaan laut dan menyukai cahaya pada malam hari. Ikan teri yang termasuk dalam famili Engraulididae ini mempunyai banyak spesies. Spesies umum yang teridentifikasi adalah Stolephorus heterobolus, S. devisii, S. buccaneeri, S. indicus, dan $S$. commersonii. (Parin, 1999).

Proses pengeringan yang sering dilakukan di Desa Ambesia Selatan masih dilakukan secara tradisional. Ikan yang digunakan adalah jenis ikan teri (Stolephorus sp). Usaha pengeringan ikan yang dilakukan masyarakat Desa Ambesia Selatan merupakan satu sumber mata pencaharian masyarakat dan sebagai salah satu peluang usaha yang dapat meningkatkan pendapatan masyarakat. Hal ini menjadi dasar pertimbangan penulis untuk melakukan Peneletian tentang pengeringan ikan teri di Desa Ambesia Selatan Kecamatan Tomini Kabupaten Parigi Moutong Provinsi Sulawesi Tengah.

\section{Metode Penelitian}

Penelitian ini dilaksanakan di Desa Ambesia Selatan Kecamatan Tomini Kabupaten Parigi Moutong Propinsi Sulawesi Tengah. Penelitian tergolong dalam penelitian deskriptif, dengan metode survey. Metode survey adalah suatu penyelidikan yang diadakan untuk memperoleh fakta-fakta dari gejala-gejala yang ada dan menerima keterangan secara faktual dari suatu kelompok atau daerah (Moh Nazir, 2002).

Teknik pengumpulan data dalam penelitian ini adalah wawancara, pengamatan, serta partisipasi aktif penulis bersama pemilik usaha pengawetan ikan di Desa Ambesia Selatan Kecamatan Tomini Kabupaten Parigi Moutong Provinsi Sulawesi Tengah. Sesuai tujuan penelitian tersebut di atas, maka ada dua metode analisis data yang digunakan yaitu analisis deskriptif kualitatif dan analisis kuantitatif. Analisis deskriptif kualitatif pada aspek teknik yaitu tentang sistim proses pengeringan atau ikan teri (Stolephorus sp.) di Desa Ambesia Selatan, meliputi persiapan bahan baku, waktu pengeringan, dan pengepakan. Sedangkan analisis secara kuantitatif akan dianalisa dengan menggunakan perhitungan sederhana dan selanjutnya ditabulasi terhadap data hasil pengamatan yang diperoleh.

Analisis tingkat pendapatan usaha pengeringan ikan teri, menggunakan rumus yang dikembangkan oleh Boediono, (1993), Pendapatan bersih usaha tani terlebih dahulu harus diketahui tingkat pendapatan total dan pengeluaran pada priode tertentu. Pendapatan total didekati dengan persamaan sebagai berikut :

$$
\mathrm{TR}=\mathrm{PxQ}
$$

Untuk mengetahui pendapatan bersih pelaku usaha pengeringan ikan teri dapat dihitung dengan menggunakan rumus sebagai berikut :

$$
\begin{array}{cl} 
& \mathrm{TR}=\mathrm{P} \times \mathrm{Q} \\
& \mathrm{TC}=\mathrm{TFC}+\mathrm{TVC} \\
\mathrm{p}=\mathrm{TR}-\mathrm{TC} & \\
\text { keterangan : } \\
\mathrm{TR} \quad=\text { total pendapatan } \\
\mathrm{P} \quad=\text { harga pokok per } \mathrm{Kg} \\
\mathrm{Q} \quad=\text { jumlah produksi }(\mathrm{Kg}) \\
\mathrm{TC} \quad \text { = biaya total } \\
\mathrm{TFC} & =\text { biaya tetap } \\
\mathrm{TVC} & =\text { biaya tidak tetap } \\
\mathrm{p} & =\text { pendapatan }
\end{array}
$$

Untuk analisis kelayakan usaha pengeringan ikan mengacu pada pendekatan rumus yang dikembangkan (Rahardi $d k k$., 2005) sebagai berikut:

$$
\mathrm{B} / \mathrm{C}=\frac{\text { Total Penerimaan }}{\text { Total Biaya }}
$$

\section{Hasil dan Pembahasan}

\section{Aspek Teknik Usaha Pengeringan Ikan Teri (Stolephorus sp).}

Berikut ini tahapan yang dilakukan dalam usaha pengerikan Ikan Teri (Stolephorus sp.) sebagai berikut:

\section{Penyediaan Bahan Baku}

Berdasarkan hasil penelitian di Desa Ambesia, bahan-bahan yang dibutuhkan untuk proses pengeringan ikan teri meliputi bahan baku ikan teri (Stolephorus sp.). Ikan teri (Stolephorus sp) pada lokasi penelitian tidak berwarna atau agak kemerahan. Sepanjang tubuhnya terdapat garis putih keperakan yang memanjang dari kepala hingga ke ekor. Ukuran tubuhnya relatif kecil sekitar $5-20 \mathrm{~cm}$. Ikan ini kebanyakan hidup bergerombol sampai ratusan atau bahkan ribuan individu. Ikan Teri (Stolephorus sp.) diperoleh dari para nelayan setempat dengan harga ikan teri Rp. $5000 \mathrm{~kg}$ (pada saat musim ikan antara bulan Agustus-November), Rp. 8000 $\mathrm{kg}$ (antara bulan Desember-Februari). Untuk 
memperoleh ikan teri kering yang bermutu baik, dibutuhkan bahan baku berupa ikan yang segar. Air yang digunakan untuk pencucian ikan tidak menggunakan air biasa, para pelaku usaha menggunakan air laut dan tidak menggunakan garam. Ikan dari hasil tangkapan nelayan langsung dicuci menggunakan air laut ditiriskan kemudian langsung diletakkan di atas rak penjemuran untuk dikeringkan.

Produk ikan asin kering yang sudah jadi perlu dijaga kualitasnya selama proses penyimpanan, transportasi dan distribusi sehingga harga jual tidak menurun. Oleh karena itu, perlu dilakukan pengepakan dan pengemasan yang baik supaya kualitasnya tidak menurun. Pengemasan bisa dilakukan dengan menggunakan bahan kayu, kertas, kardus ataupun plastik. Bahan-bahan yang digunakan selama proses pengemasan dan pengepakan disesuaikan dengan keperluan (Budiman 2004).

\section{Penyediaan Peralatan}

Berdasarkan pengamatan pada saat penelitian peralatan yang digunakan antara lain :
a) Termos
b) Ember
c) Gabus
d) Keranjang Plastik
e) Rak Penjemuran
f) Timbangan

Peralatan yang digunakan dalam pengeringan ikan teri yang disebutkan di atas mempunyai fungsi masing-masing. Adapun fungsi peralatan antara lain :

\section{a. Termos}

Digunakan sebagai wadah untuk menampung hasil tangkapan nelayan sebelum diolah menjadi ikan teri kering

b. Ember

Digunakan untuk wadah air guna mencuci ikan.

c. Gabus

Digunakan untuk proses pencucian ikan.

d. Keranjang Plastik

Digunakan untuk meniriskan ikan saat pencucian.

e. Rak Penjemuran

Digunakan untuk meletakkan ikan-ikan ketika dikeringkan, rak penjemuran tersebut terbuat dari jala dan kayu sebagai kerangkanya.

f. Timbangan

Digunakan untuk menimbang ikan setelah dikeringkan.

Semua peralatan dan perlengkapan yang digunakan dalam penanganan ikan teri kering mempunyai permukaan halus dan rata, tidak mengelupas, tidak berkarat, tidak retak dan mudah dibersihkan. Semua peralatan dalam keadaan bersih sebelum, selama dan sesudah digunakan.

\section{Proses Pengeringan}

Dari pengamatan langsung di tempat penelitian, setelah mempersiapkan bahan baku dan peralatan secukupnya, yang dikerjakan selanjutnya adalah melakukan proses pengeringan ikan teri. Adapun langkah-langkah pengeringan ikan teri sebagai berikut :

a. Pencucian: Ikan hasil tangkapan nelayang yang akan dikeringkan dicuci dengan menggunakan air laut dan ditempatkan dalam keranjang plastik.

b. Penirisan: Penirisan dilakukan untuk mengurangi kadar air.

c. Pengeringan: Pengeringan/penjemuran ikan dilakukan dengan meletakan ikan di atas rak penjemuran kemudian dijemur disinar matahari (3-4 hari, tergantung dari cuaca).

d. Dikemas.

Pengeringan dapat dilakukan dengan memanfaatkan energi surya (pengeringan alami) dan dapat juga dilakukan dengan menggunakan peralatan khusus yang digerakkan dengan tenaga listrik. Proses pengeringan bahan pangan dipengaruhi oleh luas permukaan bahan pangan, suhu pengeringan, aliran udara, tekanan uap air dan sumber energi yang digunakan serta jenis bahan yang akan dikeringkan (Hasibuan, 2005). Pengeringan adalah suatu cara untuk mengeluarkan atau menghilangkan sebagian air yang dikandung melalui penggunaan energi panas. Biasanya, kandungan air bahan tersebut dikurangi sampai batas sehingga mikrorganisme tidak dapat tumbuh lagi di dalamnya (Suwandi dan Riyanto, 2000 ).

\section{Pengemasan / Pengepakkan}

Sebelum melakukan pengemasan, terlebih dahulu ikan disortir kembali dengan tujuan untuk memastikan ikan-ikan yang akan di pasarkan memiliki kualitas yang baik menambah nilai jual ikan teri yang sudah dikeringkan. Kemudian ikan teridimasukkan ke dalam karung yang bersih, kemudian karung tersebut diikat kuat agar ikan teri yang berada dalam karung tersebut dapat terhindar dari berbagai macam kotoran seperti debu. Ikan teri yang telah dimasukkan ke dalam karung disimpan di dalam gudang penyimpanan dan siap untuk di pasarkan. 
Bahan kemasan untuk ikan teri harus bersih, tidak mencemari produk yang dikemas, terbuat dari bahan yang baik dan memenuhi persyaratan bagi produk ikan kering. Produk ikan teri sebaiknya dikemas dengan cepat, cermat secara saniter dan higienis. Pengemasan dilakukan dalam kondisi yang dapat mencegah terjadinya kontaminasi dari luar terhadap produk. Penyimpanan ikan teri dapat dilakukan didalam gudang penyimpanan dengan suhu ruang dengan suhu $5^{\circ} \mathrm{C}$

\section{Analisis Usaha Pengeringan Ikan Teri (Stolephorus sp).}

Analisis pendapatan berfungsi untuk mengukur apakah usaha pengeringan ikan teri menguntungkan atau tidak. Oleh sebab itu, ukuran yang digunakan untuk menetapkan besar pendapatan yang diterima oleh pelaku usaha pengeringan ikan teri di Desa Ambesia selatan adalah selisih antara penerimaan dengan jumlah biaya yang dikeluarkan. Analisis ekonomi untuk perhitungan pendapatan bersih secara keseluruhan 5 (lima) responden sebesar Rp.188.295.100,- per tahun, bila dihitung perorang nelayan responden, maka diperoleh pendapatan bersih pertahun Rp. 37.659.020,- dan dikonversi 12 bulan (1 tahun) nilanya mencapai Rp.3.138.251,- perbulan.

Untuk mengetahui suatu kelayakan usaha dari usaha pengeringan ikan teri di Desa Ambesia Selatan dengan rata-rata penerimaan pelaku usaha pengeringan ikan teri dalam 1 (satu) tahun adalah sebesar Rp.359.360.000,- dan total biaya rata-rata dalam 1 (satu) tahun adalah Rp.171.064.900,-. Adapun perhitungan Benefit Cost Ratio rata-rata usaha pengeringan ikan teri di Desa Ambesia Selatan adalah sebagai berikut :

$$
\begin{aligned}
\mathrm{B} / \mathrm{C} \text { Ratio } & =\frac{\text { Total Penerimaan }}{\text { Total Biaya }} \\
& =\frac{\text { Rp. } 359.360 .000}{\text { Rp.171.064.900 }} \\
& =2.10
\end{aligned}
$$

Dari perhitungan B/C Ratio di atas diperoleh hasil sebesar 2,10, hal tersebut menunjukkan bahwa usaha pengeringan ikan teri di Desa Ambesia Selatan layak untuk dikembangkan sebab hasil perhitungan B/C Ratio dari usaha tersebut lebih dari 1 (satu) (BCR > 1). Benefit Cost Rasio (BCR), adalah manfaat atau menghitung keuntungan dari suatu usaha atas investasi yang digunakan. Analisa ini merupakan perbandingan antara penerimaan dengan biaya- biaya dalam suatu produksi per satuan waktu. Apabila BC Ratio >1 maka usaha ini dikatakan layak untuk dikembangkan, BC Ratio $<1$ maka usaha ini dikatakan tidak layak untuk dikembangkan atau usaha ini mengalami kebangkrutan dan apabila BC Ratio=1 maka usaha ini tidak mengalami kerugian dan tidak mengalami keuntungan (Rahardi $d k k$., 2005).

\section{Kesimpulan}

Berdasarkan penelitian yang dilakukan di Desa Ambesia Selatan dapat ditarik kesimpulan sebagai berikut :

1. Pengeringan ikan teri di Desa Ambesia Selatan dilakukan secara tradisional, dengan proses penggaraman secara alami dan tidak menggunakan garam.

2. Bahan baku utama dalam proses pengeringan ikan adalah jenis ikan teri (Stelephorus sp.). Dengan pembelian bahan baku menggunakan ukuran termos besar dengan berat ikan teri basah $40 \mathrm{~kg}$, dengan harga Rp. 5000-Rp. 8000 per kg. Setelah proses pengeringan dihasilkan $10 \mathrm{~kg}$, dari kadar hasil dengan harga Rp 50.000 Rp 60.000 per kg.

3. Metode pengeringan yang dilakukan di Desa Ambesia Selatan adalah metode pengeringan alami, proses pengeringan yang dilakukan oleh pelaku usaha, ikan hanya dilakukan dengan memanfaatkan sinar matahari, dan lama penjemuran 2 - 3 hari.

4. Berdasarkan hasil perhitungan $\mathrm{B} / \mathrm{C}$ ratio adalah 2.10, hal tersebut menunjukkan bahwa usaha pengeringan ikan teri di Desa Ambesia Selatan layak untuk dikembangkan sebab hasil perhitungan B/C Ratio dari usaha tersebut lebih dari 1 (satu) $($ BCR $>1)$ artinya bahwa usaha pengeringan ikan teri di Desa Ambesia Selatan Layak untuk dikembangkan.

5. Untuk mengetahui tingkat pengembalian investasi dilakukan analisis perhitungan payback period. Berdasarkan perhitungan payback period dengan hasil adalah 0,02 tahun ( \pm 4 tahun masa pengembaliannya).

6. Usaha pengeringan ikan teri di Desa Ambesia Selatan harus memilih lembaga pemasaran yang tepat agar proses pemasaran produk lebih efektif sehingga dapat meningkatkan pendapatan pengolahan ikan teri kering selaku produsen. 


\section{Daftar Pustaka}

Adawiyah, R. 2007. Pengolahan dan Pengawetan Ikan. PT. Bumi Aksara. Jakarta.

Budiman, M. 2004. Teknik Penggaraman dan Pengeringan. PT. Bumi Aksara. Jakarta.

Effendi, I dan W. Oktariza. 2006. Manajemen Agribisnis Perikanan. Penebar Swadaya, Jakarta.

Hasibuan, R. 2005. Proses Pengeringan. Fakultas Teknik Kimia. Universitas Sumatera Utara, Medan.

Ismail, S. 2007. Pengolahan Ikan Asin. Penerbit PT. Penebar Swadaya, Jakarta.
Parin, N. V. 1999. Fliying Fishes (exocotidae) Of Norhwest Pacifik. Acad. Nonk. USSR. Trund Inst. Oceanol.

Pinem, 2004. Rancang Bangun Alat Pengeringan Ikan Teri Kapasitas 12kg/jam. Staf Pengajar Jurusan Teknik Mesin. Politeknik Negeri Malang. Jurnal Teknik SIMETRIKA Vol.3. No.3. 249-253

Rahardi, F. Kristiawati, R dan Nazaruddin. 2005. Agribisnis Perikanan. PT.Penebar Swadaya. Jakarta

Soekartawi, 2003. Agribisnis Teori dan Aplikasi. Edisi Pertama. Cetakan Ketujuh. PT. Raja Grafindo Ersada. Jakarta

Suwandi, E., dan Riyanto, M., 2000. Metode Pengeringan Ikan. PT. Kanisius Yogyakarta. 